\title{
Organizational and pedagogical characterization of vocational courses in nursing at SUS Schools
}

\author{
Caracterização organizacional e pedagógica dos cursos técnicos em enfermagem das Escolas do SUS \\ Caracterización organizativa y pedagógica de los cursos técnicos de enfermería en las Escuelas del SUS
}

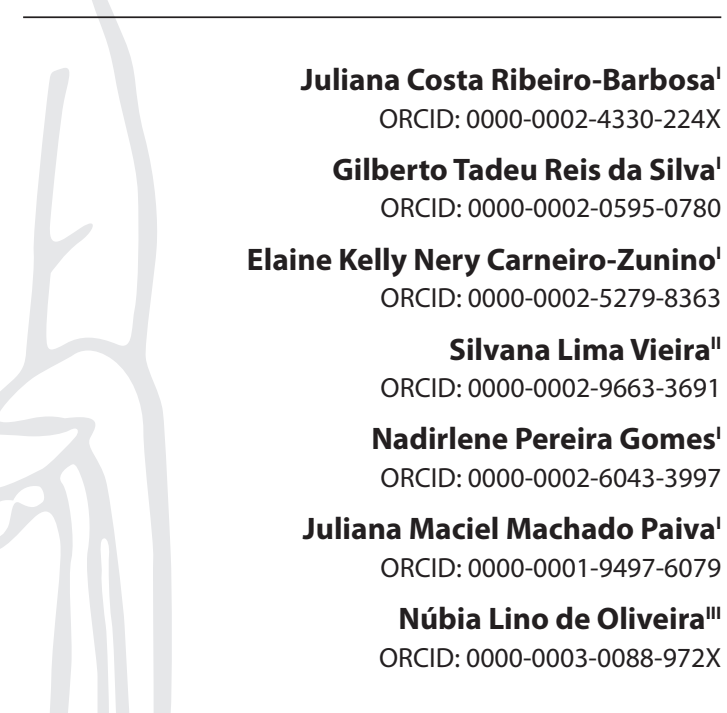

'Universidade Federal da Bahia. Salvador, Bahia, Brazil. "Universidade do Estado da Bahia. Salvador, Bahia Brazil.

I'ISecretaria Municipal da Saúde de Salvador. Salvador,

Bahia, Brazil.

How to cite this article: Ribeiro-Barbosa JC, Silva GTR, Carneiro-Zunino EKN, Vieira SL, Gomes NP, Paiva JMM, et al. Organizational and pedagogical characterization of vocational courses in nursing at SUS Schools. Rev Bras Enferm. 2021;74(1):e20190574. doi: http://dx.doi.org/10.1590/0034-7167-2019-0574

Corresponding author: Juliana Costa Ribeiro-Barbosa E-mail: enfa.jcr@hotmail.com

EDITOR IN CHIEF: Dulce Barbosa ASSOCIATE EDITOR: Italo Rodolfo Silva

Submission: 08-02-2018

Approval: 09-30-2020

\begin{abstract}
Objectives: to know the organizational and pedagogical characteristics of vocational courses in nursing of Unified Health System Vocational Schools in northeastern Brazil. Methods: this is a qualitative, descriptive study, developed in six schools that offer this course. As a data source, Pedagogical Political Project and Teaching Plans were used to search for information on courses' organizational and pedagogical characteristics through indirect documentation, using three structured scripts. Results: most of the characteristics of the courses are convergent between schools, but pedagogical characterization items do not exist, presenting themselves as fragility regarding the outline of such normative characteristics. Final Considerations: the characterization of the courses demonstrates the schools' commitment to training professionals aiming at quality of healthcare/nursing in/for the Unified Health System. However, the weakness found in the documents emerged as a challenge to be overcome, in order to better subsidize teaching and learning and qualify training.

Descriptors: Nursing Education Research; Nursing; Training, Vocational; Research, Nursing Education; Nursing Research, Educational.
\end{abstract}

\section{RESUMO}

Objetivos: conhecer as características organizacionais e pedagógicas dos cursos técnicos em enfermagem das Escolas Técnicas do Sistema Único de Saúde da Região Nordeste. Métodos: estudo qualitativo, descritivo, desenvolvido em seis escolas que ofertam este curso. Foram utilizados, como fonte de dados, o Projeto Político Pedagógico e os Planos de Ensino, em busca de informações sobre as características organizacionais e pedagógicas dos cursos, mediante documentação indireta, empregando três roteiros estruturados. Resultados: a maioria das características dos cursos é convergente entre as escolas, mas itens da caracterização pedagógica inexistem, apresentando-se como fragilidade quanto ao delineamento de tais características normativas. Considerações Finais: A caracterização dos cursos demonstra empenho das escolas para formação de profissionais visando à qualidade da atenção à saúde/enfermagem no/para o Sistema Único de Saúde. Contudo, a fragilidade encontrada nos documentos emergiu como desafio a ser superado, a fim de melhor subsidiar o ensino-aprendizagem e qualificar a formação.

Descritores: Educação Técnica em Enfermagem; Educação em Enfermagem; Enfermagem; Escolas para Profissionais de Saúde; Sistema Único de Saúde.

\section{RESUMEN}

Objetivos: conocer las características organizativas y pedagógicas de los cursos técnicos de enfermería en las Escuelas Técnicas del Sistema Único de Salud de la Región Nordeste. Métodos: estudio cualitativo, descriptivo, desarrollado en seis escuelas que ofrecen este curso. Como fuente de datos se utilizó el Proyecto Político Pedagógico y los Planes Docentes, en búsqueda de información sobre las características organizativas y pedagógicas de los cursos, a través de documentación indirecta, utilizando tres guiones estructurados. Resultados: la mayoría de las características de los cursos son convergentes entre escuelas, pero no existen elementos de caracterización pedagógica, presentándose como fragilidad en el esquema de tales características normativas. Consideraciones Finales: la caracterización de los cursos demuestra el compromiso de las escuelas con la formación de profesionales orientados a la calidad de la atención/enfermería en/para el Sistema Único de Salud, sin embargo, la debilidad encontrada en los documentos surgió como un desafío a superar, con el fin de subsidiar mejor la enseñanza y el aprendizaje y calificar la formación.

Descriptores: Educación Técnica en Enfermería; Educación en Enfermería; Enfermería; Escuelas para Profesionales de la Salud; Sistema Único de Salud. 


\section{INTRODUCTION}

Vocational training in nursing aims to provide students with essential knowledge and professional skills to professional practice and citizenship, considering the performance of the current demands of the Brazilian public health system, the Unified Health System (SUS - Sistema Único de Saúde), and the population's health needs regarding promotion, prevention, recovery and rehabilitation of health-disease processes ${ }^{(1-2)}$.

In the 1980s, in the context of strategies to deal with the disarticulation of the education and health sectors with a view to training for SUS, SUS Vocational Schools (ETSUS - Escolas Técnicas do SUS) were created. Such public institutions aimed, a priori, to qualify mid-level or elementary-level health workers employed in the Brazilian health system, having their principles and guidelines as guiding axes of the teaching plans. Currently, they are configured as a reference in Brazil for health workers' training, qualification, (re) professionalization and updating, playing a significant role in professional practice reorientation and qualification ${ }^{(3)}$.

Brazil currently has 40 ETSUS that make up the SUS Vocational Schools network, established by Ordinance 1,298/2000, which, among other objectives, intends to disseminate methodologies and technological resources aimed at improving teaching, research and vocational cooperation activities, so that it presents itself as a strategy for building knowledge in Health Professional Education. The Northeast Region, in particular, has 12 schools, of which six offer vocational training in nursing, which characterizes it as the region that, numerically, offers this course more than the others ${ }^{(4)}$.

With regard to the pedagogical dimension of this training, some normative instruments direct and facilitate the teachinglearning process, considering the reality of health and society. Among these instruments, Pedagogical Political Project (PPP) and Teaching Plans stand out, official documents with proposals and strategies that describe training values, concepts, and intentions ${ }^{(5)}$.

Therefore, it becomes opportune to think about vocational training in nursing considering its organizational and pedagogical characteristics of ETSUS in northeastern Brazil, since it is imperative its training for SUS. Moreover, the relevance of nursing technicians' performance stands out, as they corresponds to approximately $55 \%$ of the total nursing workforce, notably in the front line of care ${ }^{(6)}$.

Furthermore, there is an incipience of national studies that address vocational training in nursing, an aspect confirmed by searching the Virtual Health Library in January 2018, using the descriptor "vocational education in nursing" and the filters "vocational education in nursing", "Brazil" and "articles", which identified 11 publications. Of these, four showed duplicity, totaling seven productions only, whose dates were between 1977 and 2017. The topics covered in these productions, in general, were biosafety, occupational health, Systematization of Nursing Care and vocational training in nursing, which was focused on two works.

Specifically in the articles in which vocational training in nursing was the theme/object of investigation, the organizational and/or pedagogical characteristics of this training were not addressed, understood as essential to know the profile of professionals to be trained. The first work dealt with the historical and ethical aspects of the professional training of nursing technicians and pointed to a learning process marked by exhaustion and frustration due to the dissociation between school projects and Taylorized institutional daily life. Consequently, the second study addressed the professionalization of nursing attendants, and found a tendency to expand the offer of courses and the demand for vocational training and specializations.

Thus, considering the worry and concern with training human resources for SUS, highlighting the strategic role of Vocational Schools, focusing on the organizational and pedagogical characteristics of the courses and the decisive character occupied by mid-level vocational workers in nursing to consolidate the national policy of health, it is questioned: what are the organizational and pedagogical characteristics of vocational courses in nursing at ETSUS for training in/for SUS?

\section{OBJECTIVES}

To know the organizational and pedagogical characteristics of vocational courses in nursing of Unified Health System Vocational Schools in northeastern Brazil.

\section{METHODS}

\section{Ethical aspects}

The study observed the ethical and scientific principles for research with human beings specified in Resolution 466/2012 of the Brazilian National Health Council (Conselho Nacional de Saúde), having been approved by the Research Ethics Committee. Anonymity of co-participating schools was safeguarded, which were identified with an acronym, known as ETSUS, followed by an Arabic numeral.

\section{Type of study}

This is a qualitative and descriptive study, part of a master's dissertation entitled "Formação em Enfermagem nas Escolas Técnicas do SUS", as a fellow at the Coordination for the Improvement of Higher Education Personnel (Coordenação de Aperfeiçoamento de Pessoal de Nível Superior), with developments in Research Projects for SUS.

\section{Study setting}

This study was developed in six ETSUS located in the Northeast. Twelve schools in the region offering vocational courses in nursing were included.

The approach to co-participant institutions occurred primarily by telephone contact. A posteriori, a Letter of Introduction and Invitation, Terms of Authorization from the Co-Participating and Concession Institutions were sent by electronic mail, in addition to a copy of the project.

\section{Data collection and organization}

In order to answer the research question, we sought to identify in these documents information about the organizational and 
pedagogical characteristics of the courses. Therefore, each ETSUS was asked to send, via email, the school units' PPP and Teaching Plans for vocational courses in nursing.

PPP and Teaching Plans were used as a data source, which were made available in June 2017. These documents were chosen as they direct and facilitate the teaching-learning process with a view to adapting training to the reality of society and health, being, therefore, official documents that expose the course's profile.

Data collection took place through the indirect documentation technique ${ }^{(7)}$ through three structured scripts, which had questions related to the organizational and pedagogical characteristics of the courses. Concerning organizational characteristics, objective, workload, curriculum and profile of the intended students were considered; as for pedagogical characteristics, update and PPP elaboration staff were analyzed; menu, objectives, date of update, syllabus, teaching methodologies and assessment process of Teaching Plans. Said data constituted the corpus of the research and were compiled and organized in Microsoft ${ }^{\circ}$ Office Word for the purposes of systematization and analysis.

\section{Data analysis}

Based on research corpus analysis, which was based on Franco's content analysis ${ }^{(8)}$, the data were organized into two categories entitled: "Organizational characteristics of vocational nursing courses" and "Pedagogical characteristics of vocational nursing courses".

Data were interpreted and supported based on the current literature referring to education and, more specifically, to vocational professional education at the secondary level, in which norms and guidelines that deal with aspects at the organizational and pedagogical levels of the course on screen can be accessed, presented by the Brazilian National Education Council (Conselho Nacional de Educação). Thus, it was possible to explore, triangulate and compare data, depicting them descriptively and also representing them by means of figures and charts.

\section{RESULTS}

\section{Organizational characteristics of vocational nursing courses}

The courses' objective was convergent between the teaching units investigated, which is to train nursing technicians with social commitment and professional ethics, who act according to the population's health needs and Brazilian health system demands, with a focus on improving quality of nursing care.

The profile of the intended students was also similar between schools and was related to the development of skills to be improved by students, which involve the four dimensions of knowledge (knowing, knowing-being, knowing-doing, knowing-living).

As for workload, all schools respect the minimum 1,200 hours for the course. However, there is a variation in the total workload due to the addition of the workload related to the curriculum component Supervised Practice, so that four schools make 1,800 hours and the remaining two make 1,890 and 1,440 hours (Figure 1).

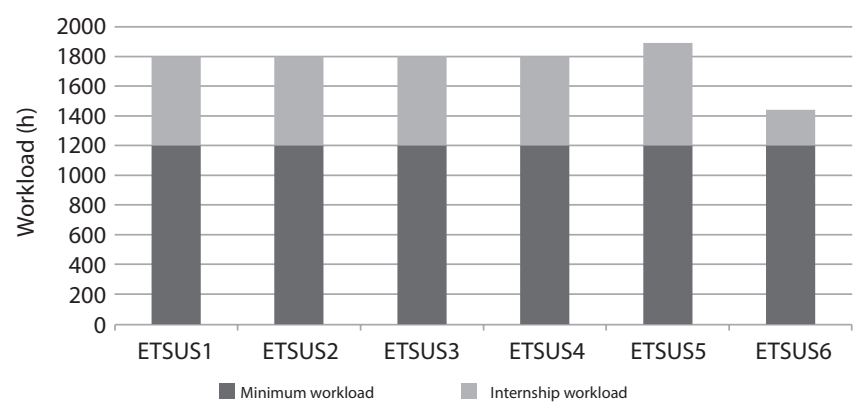

Note: ETSUS - Escolas Técnicas do Sistema Único de Saúde (Unified Health System Vocational Schools). Figure 1 - Distribution of the workload of vocational nursing courses at Unified Health System Vocational Schools (Escolas Técnicas do Sistema Único de Ssaúde) in northeastern Brazil, Salvador, Bahia, Brazil, 2018

With regards to curriculum, all schools adopt the competency model, the update of which was not informed by two schools, and the most current curriculum dates from 2016.

\section{Pedagogical characteristics of vocational nursing courses}

Concerning Pedagogical Political Project elaboration/update, Chart 1 describes some characteristics, namely date and actors involved:

Chart 1 - Pedagogical Political Project elaboration/update of Unified Health System Vocational Schools (Escolas Técnicas do Sistema Único de Ssaúde) in northeastern Brazil according to date and actors involved, Salvador, Bahia, Brazil, 2018

\begin{tabular}{|c|c|c|}
\hline ETSUS & Date & Actors involved \\
\hline ETSUS1 & 2016 & Managers \\
\hline ETSUS2 & 2007 & Managers, teachers, students, vocational staff \\
\hline ETSUS3 & 2016 & Managers, students, teachers, families \\
\hline ETSUS4 & 2014 & Multidisciplinary staff, ETSUS actors \\
\hline ETSUS5 & 2013 & Not included \\
\hline ETSUS6 & 2016 & Vocational staff, teachers, students \\
\hline
\end{tabular}

It is worth noting the fact that at ETSUS1 only the management staff shared the process of building PPP, while the external community participation, represented by the family, occurred exclusively at ETSUS3.

Teaching Plans, on the other hand, conform to a single document, configuring themselves as the main and guiding file of the course. In this document, therefore, information about the vocational course in nursing's specificities is described, especially in relation to the distribution and conformation of teaching units (Chart 2).

It is noted that there are items related to the details of Teaching Plans that are not included in the analyzed documents, which present gaps in the outlining of such characteristics. 
Chart 2 - Detailing of teaching plans for vocational nursing courses at Unified Health System Vocational Schools (Escolas Técnicas do Sistema Único de Ssaúde) in northeastern Brazil, Salvador, Bahia, Brazil, 2018

\begin{tabular}{|c|c|c|c|c|c|c|c|}
\hline $\begin{array}{c}\text { Teaching } \\
\text { plans }\end{array}$ & Date & Menu & Goals & Syllabus & $\begin{array}{c}\text { Teaching } \\
\text { Methodology }\end{array}$ & Assessment & References \\
\hline ETSUS1 & Not included & Not listed & $\begin{array}{c}\text { Detailed by } \\
\text { teaching units }\end{array}$ & $\begin{array}{c}\text { Described } \\
\text { sequentially }\end{array}$ & Questioning & $\begin{array}{c}\text { Procedural and } \\
\text { continuous. }\end{array}$ & Not listed \\
\hline ETSUS2 & 2015 & Not listed & Not listed & Not listed & Questioning & $\begin{array}{c}\text { Procedural and } \\
\text { continuous. }\end{array}$ & Not listed \\
\hline ETSUS3 & 2012 & Not listed & $\begin{array}{c}\text { Detailed by } \\
\text { teaching units }\end{array}$ & $\begin{array}{c}\text { Described } \\
\text { sequentially }\end{array}$ & Questioning & $\begin{array}{c}\text { Procedural and } \\
\text { continuous. }\end{array}$ & $\begin{array}{c}\text { Not listed } \\
\text { Pescribed } \\
\text { continuous. }\end{array}$ \\
\hline ETSUS4 & 2013 & They are & $\begin{array}{c}\text { Detailed by } \\
\text { teaching units }\end{array}$ & $\begin{array}{c}\text { Detailed by } \\
\text { teaching units }\end{array}$ \\
\hline ETSUS5 & 2013 & Not listed & $\begin{array}{c}\text { Detailed by } \\
\text { teaching units }\end{array}$ & $\begin{array}{c}\text { Described } \\
\text { sequentially }\end{array}$ & Not included & $\begin{array}{c}\text { Procedural and } \\
\text { continuous. }\end{array}$ & Not listed \\
\hline ETSUS6 & 2016 & Not listed & $\begin{array}{c}\text { Detailed by } \\
\text { teaching units }\end{array}$ & $\begin{array}{c}\text { Described } \\
\text { sequentially }\end{array}$ & Questioning & $\begin{array}{c}\text { Procedural and } \\
\text { continuous. }\end{array}$ & Not listed \\
\hline
\end{tabular}

Note: ETSUS - Escolas Técnicas do Sistema Único de Saúde (Unified Health System Vocational Schools).

\section{DISCUSSION}

This study showed that the objective of training technicians was focused on improving nursing care quality, considering social commitment and professional ethics, according to the population's health needs and SUS demands, keeping relation with a training that concomitantly guarantees a vocational training of excellence and ethical and social relevance. In this regard, it is noted that the training allows the understanding of the need for health care, as well as the commitment to citizenship and to SUS.

Training processes are a valuable resource for the Brazilian health system consolidation; therefore, they are fundamental to align SUS principles and guidelines with what health courses aim at training professionals ${ }^{(9)}$. In the case of vocational course in nursing, this alignment becomes even more imperative, both due to its attributions in direct care to individual-family-community and the expressive contingent of workers belonging to this category $^{(6,10)}$.

The intended profile of students, therefore, was based on the dimensions of knowledge that relate to the four pillars of education for the $21^{\text {st }}$ century ${ }^{(11)}$. Therefore, students need to overcome the limits of knowledge, endeavoring to acquire skills and attitudes, including relational ones, developing competences based on multidimensions, in which professionals develop skills to perform their function with reliability, reverberating the knowledge in concrete actions ${ }^{(12-13)}$. Thus, the profile of students should be focused on a skill development model with the purpose of overcoming the centrality in content conveying, in favor of a more active, interdisciplinary and contextualized teaching.

This statement converges with the Brazilian National Curriculum Guidelines for Mid-Level Vocational Education (Diretrizes Curriculares Nacionais para a Educação Profissional Técnica de Nível Médio), which signal to the competences in the proposition of providing an education in which workers are able to mobilize and articulate knowledge and skills necessary for the efficient and effective performance of activities required by the nature of the work ${ }^{(1)}$. However, there are still discussions about how this training encourages a critical reading of society and the world in which it lives, with a view to intervention and transformation.

With regard to workload, all courses respected the minimum amount of 1,200 hours required. However, the supervised practice's workload was divergent, ranging from 240 hours to 600 hours. It is relevant to highlight that, currently, there is no specific and clear definition regarding the workload of the internship; however, it is indicated that it be added to the minimum workload assigned to the course ${ }^{(14)}$. Such lack of definition points to a certain fragility in the training process, since the approximation and appropriation of the reality of work is a central gear in professional training.

Considering this and considering that professional education is at the heart of qualifying for work and in the practical development of its tasks ${ }^{(1)}$, it is essential to consider a satisfactory workload to improve the skills necessary for working. Competency is revealed in practice and it is in the internship, practical moment and experience of the reality of work, that the opportunity for training and improvement of knowledge, skills and attitudes is realized ${ }^{(15)}$.

Furthermore, it is indispensable because it allows the courses to have a defining and normative orientation. Additionally, it offers students the guarantee of a time and space, supported and strategic, for the development of the professional skills desired for nursing technicians in SUS.

In relation to PPP, it was observed that one of the Schools made its last update in 2007, a characteristic that qualifies it as watertight and outdated. The continuous updating of PPP as a result of a process of assessment and discussion of what worked or not is extremely important for the quality of the education that is intended, since it allows for self-correction and directs the possibility of changes and reprogramming to reach the goal wanted ${ }^{(16)}$.

It was also noted that only one of PPPs had the participation of the entire school community. PPP is an instrument for coordinating activities and actions to be developed by the multiple subjects involved in the educational process and it is understood that, for this, it must be developed collectively and democratically and constantly updated ${ }^{(17)}$. Therefore, dialogue between all school actors is essential, so that the elaboration is done together, in 
order to translate their needs, desires and ideals. Furthermore, this joint and interactive practice allows for democratic action that confers rights and co-responsibilities and, in addition, strengthens institutional autonomy and transparency.

Allusive to Teaching Plans, they must be consistent with PPP and, mandatorily, contain a minimum of items that characterize and define the pedagogical proposal for vocational courses ${ }^{(1)}$. In turn, the Teaching Plans of the courses surveyed were fragile, since gaps were found in terms of details in the date of update, menu, objectives, syllabus, teaching methodology and references, so that the existing information debate the execution of the outlined proposal and the training in focus.

Another weakness identified has to do with lack of menus, which constitute the record, in summary, of the essential points that will be addressed in the curricular component, configuring itself as a basic and fundamental descriptive element for directing the teachinglearning proposal ${ }^{(18)}$. Thus, it is worth reflecting how the proposal of the themes and contents of the curricular components occurs. Absence of menus compromises such a plan and may hinder the development of educational practice. Still, it is worth noting that the text of the Brazilian National Curriculum Guidelines for Mid-Level Vocational Education recommends that this practice happen in an interdisciplinary manner, comprising dialogue, articulation and communication between the curricular components ${ }^{(1)}$.

When analyzing all Teaching Plans, it was also observed that in seven of them, bibliographic references were not described, meeting the ministerial recommendations that advocate that the curriculum components should suggest their respective reference, both basic and complementary ${ }^{(1)}$. The basic references refer to the texts that will actually be addressed and used in class and the complementary ones subsidize the expansion and deepening of the theme.

There was also a convergence in the teaching methodology adopted by the courses. Five of these adopt the problematization, which is consistent with the training proposal for SUS. This type of active learning methodology implies a break with traditional teaching, centered on teachers as a mere transmitter of information to students, and strengthening students as subjects, protagonists of their learning process, based on problems extracted from reality, seeking to identify them and solve them, transforming it ${ }^{(19)}$.

In the context of vocational education in nursing, this methodology was configured as an aspect that enhances recognizing professionals as agents for transforming the reality of health, since it enables learning referenced in reality, in a tangible problem, with a view to developing a reflective, critical and interventionist attitude ${ }^{(20)}$.

Regarding the assessment of learning, it was found that all schools work in a procedural and continuous way. Assessment is an important element of educational practice, constituting a subsidiary of decisions regarding learning; through this, it is possible to identify and understand some factors that facilitate or hinder the construction of knowledge by students ${ }^{(21)}$. In the case of vocational education in nursing, assessment gains even more emphasis, insofar as it allows reflection and the resumption of action, with a view to achieving the intended objectives - training of excellence and improving the quality of health care.

With regard to the details of the other items constituting Teaching Plans, completion was made only by one of the courses studied. This, therefore, can compromise the productivity of teaching and the guarantee of learning. Planning allows the structuring, organization and decision of the best way to reach the proposed objectives, in order to guarantee the objectivity, functionality and effectiveness of the planned actions ${ }^{(18)}$.

Considering the above, the organizational and pedagogical characterization of vocational courses in nursing points to training in and for SUS, but it presents significant weaknesses demonstrated from the gaps in the detailing of pedagogical documents. These weaknesses, therefore, pose urgent challenges to be overcome with a view to qualification in vocational training in nursing.

\section{Study limitations}

The limitations were related to a data collection performed in a documentary manner, which restricted the analysis of the subjects and actors involved in the course offer, so that there may be dissonance between the proposed and the executed.

\section{Contributions to nursing}

Studies that contribute to re (thinking) the vocational training in nursing for the Brazilian health system are highlighted, since they can meet the fragility of scientific production in this field, contributing to the construction of knowledge. Furthermore, they can make it even more evident how much it is necessary to research about this training, given its importance due to the fact that nursing technicians contemplate the largest workforce in this field and provide direct care to individual-family-community.

\section{FINAL CONSIDERATIONS}

This study signaled that most of the organizational characteristics of vocational nursing courses at ETSUS in northeastern Brazil are convergent. There is an alignment between the courses, which contributes to the strengthening of the SUS Vocational Schools network. However, the pedagogical documents showed expressive fragility regarding their details, mainly in relation to the menus, the syllabus and the bibliographic references.

Considering the results found, there is a need for research on this topic to reflect vocational training in nursing, in the various regions of the country, in order to deepen the understanding of the theme and to verify whether the results found are represented from other sources dice. It is essential to discuss about this training, considering its distance from vocational education to the world of work and its approach to pedagogical proposals that seek a comprehensive and transforming training.

As a potential, it is considered that the information concerning the strengths and the improvement of the courses on screen are subsidiary to face and overcome the difficulties of vocational training in ETSUS, with a view to improving health care and SUS.

\section{FUNDING}

This study was financed by Bahia Research Support Foundation (SUS Research Program - Notice 030/2013). Coordination for the Improvement of Higher Education Personnel (Social Demand Program). 


\section{REFERENCES}

1. Conselho Nacional de Educação (BR). Resolução CNE/CEB n6, de 20 de setembro de 2012. Institui Diretrizes Curriculares Nacionais para a Educação Técnica de Nível Médio [Internet]. Brasília, 2012 [cited 2016 Jul 13]. Available from: http://www.ifrs.edu.br/site/midias/arquivos/20 14113112619550rceb006_12-1.pdf

2. Vieira SL, Silva GTR. Educação profissional técnica de nível médio em saúde e em enfermagem: diálogo com o pensamento freireano. Estud IAT [Internet]. 2019 [cited 2020 Jul 30];4(2):126-41. Available from: http://estudosiat.sec.ba.gov.br/index.php/estudosiat/article/ viewFile/136/178

3. Galvão EA, Sousa MF. As escolas técnicas do SUS: que projetos político-pedagógicos as sustentam? Physis Rev Saúde Coletiva [Internet]. 2012 [cited 2017 Jul 15];22(2):1159-89. Available from: http://www.scielo.br/pdf/physis/v22n3/17.pdf

4. Rede de Escolas Técnicas do SUS. Escola Politécnica de Saúde Joaquim Venâncio/Fiocruz (RETSUS) [Internet]. 2017 [cited 2018 Jan 14$].$ Available from: www.retsus.epsjv.fiocruz.br

5. Nogueira MZL, Brito SMF. Projeto Político Pedagógico: uma estratégia para o sucesso da Gestão Escolar. Id on Line Rev Psicol. 2017;10(33):300-19. doi: 10.14295/idonline.v10i33.623

6. Conselho Federal de Enfermagem (Cofen). Enfermagem em números [Internet]. 2017 [cited 2017 Feb 15]. Available from: http://www.cofen. gov.br/enfermagem-em-numeros

7. Marconi MA, Lakatos EM. Fundamentos de metodologia científica. 8 ed. São Paulo: Atlas; 2017.

8. Franco MLPB. Análise de conteúdo. 4 ed. Brasília: Liber Livro Ltda; 2012.

9. Passos E, Carvalho YM. The formation for SUS, opening new trails for the production of the common. Saude soc. 2015;24(1):92-101. doi: $10.1590 /$ S0104-12902015S01008

10. Oliveira A, Marin MJS, Takeda E, Pinheiro OL. Challenges in the end-of-course paper for nursing technical training. Rev Bras Enferm. 2017;70(6):1212-19. doi: 10.1590/0034-7167-2016-0105

11. Neves VNS, Prestes EMT, Sabino RN, Silva MLN, Barros AG. Four pillars of education for the twenty-first century in the Continuing education of health professionals. Rev Enferm UFPE. 2016;10(Supl.4):3524-30. doi: 10.5205/reuol.9681-89824-1-ED.1004sup201603

12. Prados RMN, Fernandez SAF. Educação profissional no Brasil: reflexões sobre discurso político-educacional, currículo e formação técnica. Rev Devir Educ [Internet]. 2018 [cited 2020 Jul 30];2(2):90-100. Available from: http://devireducacao.ded.ufla.br/index.php/DEVIR/article/view/104/69

13. Sacristán JG. Dez teses sobre a aparente utilidade das competências em educação. In: Sacristán JG, Gómez ÁLP, Rodríguez JBM, Santomé JT, Rasco FA, Méndez JMA. Educar por competência: o que há de novo? São Paulo: Artmed; 2011.

14. Presidência da República (BR). Lei no 11.788, de 25 de setembro de 2008. Dispõe sobre o estágio de estudantes [Internet]. Brasília, 2008 [cited 2018 Jul 13]. Available from: http://www.planalto.gov.br/ccivil_03/_ato2007-2010/2008/lei/111788.htm

15. Perrenoud P. Construire des compétences, est-ce tourner le dos aux savoirs. Résonances [Internet]. 1998 [cited 2017 Dec 20];3:03-7. Available from: https://www.unige.ch/fapse/SSE/teachers/perrenoud/php_main/php_1998/1998_34.html

16. Fernandes CF, Martins C, Brittos E, Silveira FF, Bittencourt RL. Concepções e práticas de PPP em escolas do Extremo Sul Catarinense. Saberes Pedagóg [Internet]. 2018 [cited 2017 Dec 21];2(1):161-86. Available from: http://periodicos.unesc.net/pedag/article/view/3721/3452

17. Cardoso Jr HM, Brito PF, Lunas DAL, Sousa TWA. Dimensões da construção e execução do projeto político pedagógico: um estudo de caso. educação. 2017;42(2):451-66. doi: 10.5902/1984644424745

18. Silva SFC, Rocha MRC. Processo pedagógico: do planejamento ao plano de curso. Rev Com Censo [Internet]. 2018 [cited 2020 Jul 30];5(1):97101.Available from: http://www.periodicos.se.df.gov.br/index.php/comcenso/article/view/296/241

19. Berbel NAN. Metodologia da problematização: respostas de lições extraídas da prática. Semina: Ciên Soc Hum. 2014;35(2):61-76. doi: $10.5433 / 1679-0383.2014 v 35 n 2 p 61$

20. Xavier LN, Oliveira GL, Gomes AA, Machado MFAS, Eloia SMC. Analisando as metodologias ativas na formação dos profissionais de saúde: uma revisão integrativa. Sanare [Internet]. 2014 [cited 2017 Dec 22];13(1):76-83. Available from: https://sanare.emnuvens.com.br/sanare/ article/view/436/291

21. Luckesi CC. Avaliação da aprendizagem escolar. Estudos e proposições. 22a ed. São Paulo: Cortez; 2014. 